Рекомендована д. біол. наук, проф. Л.С. Фірою

УДК 582.572.8:547.631.7

\title{
ВМІСТ АМІНОКИСЛОТ У ПІДЗЕМНИХ І НАДЗЕМНИХ ОРГАНАХ ЛІЛІЙНИКА БУРО-ЖОВТОГО (НЕМЕRОСALLIS FULVA L.) ТА ЛІЛІЙНИКА ГІБРИДНОГО (HEMEROCALLIS HYBRIDA VAR. «STELLA DE ORO»)
}

\author{
๔С. М. Марчишин ${ }^{1}$, О. В. Зарічанська² \\ ${ }^{1}$ Тернопільський державний медичний університет імені І. Я. Горбачевського \\ ${ }^{2}$ Вінницький національний медичний університет імені М. І. Пирогова
}

\begin{abstract}
Резюме: здійснено дослідження амінокислотного складу коренебульб, листків і квіток лілійника буро-жовтого (Hemerocallis fulva L.) та лілійника гібридного (Hemerocallis hybrida var. «Stella De Oro»). Методом високоефективної рідинної хроматографії встановлено загальний вміст амінокислот у сировині та вміст вільних амінокислот. Виявлено 17 амінокислот, 9 з яких є незамінними. Визначено їх кількісний вміст.
\end{abstract}

Ключові слова: амінокислоти, надземні та підземні органи, лілійник буро-жовтий, лілійник гібридний, високоефективна рідинна хроматографія.

Вступ. Лілійник буро-жовтий (Hemerocallis fulva L.) та лілійник гібридний (Hemerocallis hybrida var. «Stella De Oro») - види декоративно-квіткових рослин, що належать до родини Xanthorrhoeaceae роду Hemerocallis L. В Україні види роду Лілійник (Hemerocallis L.) культивуються 3 метою озеленення завдяки їх високодекоративним квіткам. Лілійник буро-жовтий (Hemerocallis fulva L.) також зустрічається в дикорослому вигляді. В Китаї, Японії, Північній Америці, де види роду Лілійник (Hemerocallis L.) широко розповсюджені в дикій природі, підземні й надземні органи цих рослин здавна використовували в народній медицині. Водні витяги 3 коренебульб застосовують при лікуванні гінекологічних захворювань, захворювань печінки, підшлункової залози і шкіри. Настої листків і квіток лілійників рекомендують як знеболювальні, антидепресивні, заспокійливі і тонізуючі, ранозагоювальні засоби [13, 14].

Наукова література місить недостатньо даних про хімічний склад вегетативних і генеративних органів лілійників, а також про їх використання в науковій медицині. Тому встановлення якісного складу і дослідження кількісного місту біологічно активних речовин сировини розповсюджених видів роду Лілійник (Hemerocallis L.) є перспективним напрямком наукових досліджень.

Дослідження амінокислотного складу коренебульб, квіток і листків лілійника буро-жовтого та лілійника гібридного доцільне у зв'язку з тим, що амінокислоти, окрім важливого функціонального значення і специфічної фармакологічної активності, мають вплив на розвиток сумарного фармакологічного ефекту сировини і препаратів з неї. Амінокислоти відносять до речовин первинного біосинтезу рослинних організмів, тому їх рослинні джерела заслуговують на поглиблене вивчення [2, 3, 4, 5].

Мета роботи - дослідження якісного складу і кількісного вмісту амінокислот коренебульб, листків і квіток лілійника буро-жовтого (Hemerocallis fulva L.) та лілійника гібридного (Hemerocallis hybrida var. "Stella De Oro»).

Методи дослідження. Об'єктами для досліджень були коренебульби, квітки та листки лілійника гібридного (Hemerocallis hybrida var. "Stella De Oro») і лілійника буро-жовтого (Hemerocallis fulva L.). Листки та квітки заготовляли під час масового цвітіння рослин, коренебульби - восени після відмирання надземної частини на дослідних ділянках Національного ботанічного саду імені М. М. Гришка НАН України.

Якісний склад та кількісний вміст амінокислот визначали на рідинному хроматографі Agilent 1200 (Agilent technologies, USA). Проводили екстракцію вільних амінокислот із рослинної сировини та кислотний гідроліз рослинних витягів 3 наступним аналізом гідролізатів методом високоефективної рідинної хроматографії [11].

Ідентифікацію амінокислот проводили шляхом порівняння часу утримання 3 розчинами порівняння стандартів амінокислот (Agilent 50613334). Вміст зв'язаних амінокислот визначали шляхом віднімання вмісту вільних амінокислот від їх загального вмісту [10, 11, 12].

Результати й обговорення. Методом високоефективної рідинної хроматографії провели визначення якісного складу та встановили кількісний вміст амінокислот у сировині: ЛБЖБ - лілійника буро-жовтого коренебульби; лГБ лілійника гібридного коренебульби; ЛБЖК -

ISSN 2312-0967. Pharmaceutical review. 2015. № 1 
лілійника буро-жовтого квітки; ЛГК - лілійника гібридного квітки; ЛБЖЛ - лілійника буро-жовтого листки; ЛГЛ - лілійника гібридного листки.

У коренебульбах лілійника буро-жовтого ідентифіковано 8 вільних незамінних амінокислот та 7 вільних замінних; у коренебульбах лілійника гібридного - 9 і 7 відповідно. Проаналізувавши амінокислотний склад квіток лілійника буро-жовтого та лілійника гібридного, в обох об'єктах виявлено 9 вільних незамінних та 8 вільних замінних амінокислот. У результаті дослідження у листках лілійника буро-жовтого ідентифіковано 9 вільних незамінних амінокислот та 8 вільних замінних; у листках лілійника гібридного - 8 і 7 відповідно. Результати аналізу наведено у таблицях 1 і 2.

Аналіз загального вмісту амінокислот у рослинній сировині обох видів лілійника показав, що ЛБжЛ містять значну кількість лейцину (792 мг/100 г), фенілаланіну (617 мг/100 г), ізолейцину (542 мг/100 г) з незамінних амінокислот; глутамінової кислоти (3245 мг/100 г), цистеїну (1166 мг/100 г), аспарагінової кислоти (826 мг/100 г) з замінних. Високий загальний вміст аспарагінової кислоти спостерігається у ЛБЖБ і ЛБЖК - 1044 мг/100 г і 808 мг/100 г відповідно. У ЛГБ, ЛГК і ЛГЛ також спостерігається високий загальний вміст аспарагінової кислоти 959, 974 і 928 мг/100 г відповідно. У ЛГК і ЛГЛ виявлено значну загальну кількість глутамінової кислоти - 1835 мг/100 г і 1396 мг/100 г відповідно.

Отже, результати порівняльного аналізу свідчать, що досліджувані об'єкти в значній кількості вміщують замінні амінокислоти: глутамінову та аспарагінову кислоти, з незамінних фенілаланін, лейцин і лізин. Відомо, що аспарагінова і глутамінова кислоти займають центральне місце у процесах зв'язування, транспорту і виведення 3 організму біологічно активних форм азоту. Вони сприяють підтриманню азотистого балансу живих організмів [1, 8]. Аспарагінова кислота $€$ попередником оротової кислоти та піримідинів, які проявляють імуностимулюючу дію; глутамінова - бере участь у біосинтезі ДНК та РНК, покращує білковий та вуглеводний обмін, сприяє енергетичному забезпеченню функцій головного мозку. Лейцин має здатність знижувати рівень цукру в крові і стимулювати виділення гормону росту; фенілаланін $€$ попередником пігменту шкіри меланіну, а також тирозину, з якого синтезуются такі біологічно ак-

Таблиця 1. Амінокислотний склад коренебульб, квіток і листків лілійника буро-жовтого (Hemerocallis fulva L.)

\begin{tabular}{|c|c|c|c|c|c|c|c|}
\hline \multirow[b]{2}{*}{$\begin{array}{l}\text { № } \\
\Pi / \Pi\end{array}$} & \multirow[b]{2}{*}{ Амінокислоти } & \multicolumn{2}{|c|}{ ЛБЖБ } & \multicolumn{2}{|c|}{ ЛБЖК } & \multicolumn{2}{|c|}{ ЛБЖЛ } \\
\hline & & $\begin{array}{c}\text { загальний } \\
\text { вміст АК, } \\
\text { мг/100г }\end{array}$ & $\begin{array}{c}\text { вміст } \\
\text { вільних } \\
\text { АК, } \\
\text { мг/100г }\end{array}$ & $\begin{array}{c}\text { загальний } \\
\text { вміст АК, } \\
\text { мг/100г }\end{array}$ & $\begin{array}{c}\text { вміст } \\
\text { вільних } \\
\text { АК, } \\
\text { мг/100г }\end{array}$ & $\begin{array}{c}\text { загальний } \\
\text { вміст АК, } \\
\text { мг/100г }\end{array}$ & $\begin{array}{c}\text { вміст } \\
\text { вільних } \\
\text { АК, } \\
\text { мг/100г }\end{array}$ \\
\hline \multicolumn{8}{|c|}{ Незамінні АК } \\
\hline 1 & Аргінін & 239 & 151 & 308 & 65 & 472 & 141 \\
\hline 2 & Валін & 102 & 10 & 396 & 81 & 531 & 185 \\
\hline 3 & Гістидин & 82 & 24 & 211 & 40 & 169 & 63 \\
\hline 4 & Ізолейцин & 110 & 11 & 387 & 77 & 542 & 180 \\
\hline 5 & Лейцин & 143 & 2 & 526 & 94 & 792 & 223 \\
\hline 6 & Лізин & 152 & 31 & 624 & 45 & 446 & 76 \\
\hline 7 & Метіонін & 20 & - & 46 & 13 & 104 & 8 \\
\hline 8 & Треонін & 89 & 8 & 317 & 70 & 464 & 157 \\
\hline 9 & Фенілаланін & 136 & 25 & 403 & 89 & 617 & 198 \\
\hline CyN & а вмісту незамінних АК & 1072 & 262 & 3218 & 574 & 4137 & 1231 \\
\hline \multicolumn{8}{|c|}{ Замінні АК } \\
\hline 10 & Аланін & 108 & 13 & 546 & 174 & 538 & 155 \\
\hline 11 & Аспарагінова кислота & 1044 & 36 & 808 & 38 & 826 & 55 \\
\hline 12 & Гліцин & 84 & 1 & 380 & 36 & 429 & 25 \\
\hline 13 & Глутамінова кислота & 429 & 45 & 2502 & 125 & 3245 & 231 \\
\hline 14 & Пролін & 79 & 2 & 362 & 71 & 579 & 202 \\
\hline 15 & Серин & 78 & 7 & 395 & 129 & 423 & 115 \\
\hline 16 & Тирозин & 33 & 6 & 135 & 48 & 203 & 71 \\
\hline 17 & Цистеїн & 210 & - & 467 & - & 1166 & 35 \\
\hline \multicolumn{2}{|c|}{ Сума вмісту замінних АК } & 2125 & 110 & 5595 & 621 & 7409 & 889 \\
\hline \multicolumn{2}{|c|}{$\begin{array}{l}\text { Сума вмісту незамінних та } \\
\text { замінних АК }\end{array}$} & 3198 & 372 & 8813 & 1195 & 11546 & 2120 \\
\hline
\end{tabular}

ISSN 2312-0967. Фармацевтичний часопис. 2015. № 1 
Фітохімічні дослідження

Phytochemical researches

Таблиця 2. Амінокислотний склад коренебульб, квіток і листків лілійника гібридного (Hemerocallis hybrida var. "Stella De Oro")

\begin{tabular}{|c|c|c|c|c|c|c|c|}
\hline \multirow[b]{2}{*}{$\begin{array}{l}\text { № } \\
\Pi / \Pi\end{array}$} & \multirow[b]{2}{*}{ Амінокислоти } & \multicolumn{2}{|c|}{ ЛГБ } & \multicolumn{2}{|c|}{ ЛГК } & \multicolumn{2}{|c|}{ ЛГЛ } \\
\hline & & $\begin{array}{c}\text { загальний } \\
\text { вміст АК, } \\
\text { мг/100г }\end{array}$ & $\begin{array}{c}\text { вміст } \\
\text { вільних } \\
\text { АК, } \\
\text { мг/100г }\end{array}$ & $\begin{array}{c}\text { загальний } \\
\text { вміст АК, } \\
\text { мг/100г }\end{array}$ & $\begin{array}{c}\text { вміст } \\
\text { вільних } \\
\text { АК, } \\
\text { мг/100г }\end{array}$ & $\begin{array}{c}\text { загальний } \\
\text { вміст АК, } \\
\text { мг/100г }\end{array}$ & $\begin{array}{c}\text { вміст } \\
\text { вільних } \\
\text { АК, } \\
\text { мг/100г }\end{array}$ \\
\hline \multicolumn{8}{|c|}{ Незамінні АК } \\
\hline 1 & Аргінін & 241 & 180 & 278 & 106 & 498 & 14 \\
\hline 2 & Валін & 107 & 17 & 349 & 144 & 369 & 43 \\
\hline 3 & Гістидин & 75 & 19 & 150 & 64 & 280 & 270 \\
\hline 4 & Ізолейцин & 113 & 18 & 430 & 139 & 425 & 36 \\
\hline 5 & Лейцин & 145 & 4 & 460 & 166 & 519 & 44 \\
\hline 6 & Лізин & 151 & 23 & 480 & 115 & 698 & 10 \\
\hline 7 & Метіонін & 18 & 2 & 77 & 23 & 52 & - \\
\hline 8 & Треонін & 96 & 17 & 277 & 115 & 400 & 28 \\
\hline 9 & Фенілаланін & 136 & 32 & 393 & 165 & 502 & 36 \\
\hline Cys & а вмісту незамінних АК & 1082 & 312 & 2894 & 1037 & 3743 & 481 \\
\hline \multicolumn{8}{|c|}{ Замінні АК } \\
\hline 10 & Аланін & 123 & 27 & 520 & 234 & 409 & 73 \\
\hline 11 & Аспарагінова кислота & 959 & 38 & 974 & 74 & 928 & 18 \\
\hline 12 & Гліцин & 92 & 2 & 295 & 50 & 328 & 4 \\
\hline 13 & Глутамінова кислота & 497 & 56 & 1835 & 218 & 1396 & 62 \\
\hline 14 & Пролін & 85 & 5 & 370 & 162 & 341 & 51 \\
\hline 15 & Серин & 96 & 16 & 369 & 169 & 362 & 21 \\
\hline 16 & Тирозин & 35 & 12 & 101 & 98 & 245 & 13 \\
\hline 17 & Цистеїн & 202 & - & 445 & 68 & 753 & - \\
\hline \multicolumn{2}{|c|}{ Сума вмісту замінних АК } & 2089 & 156 & 4909 & 1073 & 4762 & 242 \\
\hline \multicolumn{2}{|c|}{$\begin{array}{l}\text { Сума вмісту незамінних та } \\
\text { замінних АК }\end{array}$} & 3171 & 468 & 7803 & 2110 & 8505 & 723 \\
\hline
\end{tabular}

тивні речовини, як адреналін, норадреналін, дофамін [6, 7, 9].

Результати досліджень показали, що зразки сировини двох видів лілійника характеризується неоднаковим амінокислотним складом та відрізняються кількісним вмістом амінокислот. Отримані результати є підставою для поглибленого вивчення коренебульб, квіток і листків лілійника буро-жовтого і лілійника гібридного як джерел природних біологічно активних сполук.

Висновки. 1. Вперше вивчено амінокислотний склад коренебульб, квіток і листків лілійника буро-жовтого і лілійника гібридного.

2. Встановлено, що найвищий загальний вміст амінокислот і вміст вільних амінокислот виявлено у листках лілійника буро-жовтого, найнижчий - у коренебульбах лілійника гібридного.

\section{Література}

1. Амінокислотний склад арніки гірської та арніки листяної / С. М. Марчишин, О. Л. Демидяк // Фармацевтичний часопис. - 2008. - № 2. - С. 48-51.

2. Ісюк М. В. Дослідження амінокислотного складу герані сибірської / М. В. Ісюк, І. Л. Бензель, Л. В. Бензель // Актуальні питання фармацевтичної і медичної науки та практики. - 2012. - № 3 (10). - С. 4-6.

3. Волочай В. І. Вивчення амінокислотного складу трави галінсоги дрібноквіткової та галінсоги війчастої / В. І. Волочай, В. М. Ковальов // Запорожский медицинский журнал. - 2012. - № 3 (72). - С. 44-46.

4. Вивчення амінокислотного складу трави Artemisia balchanorum Krasch. i Artemisia taurica Willd / K. B. Be-

реднікова, О. К. Єренко, О. В. Мазулін, І. В. Полевик // Актуальні питання фармацевтичної і медичної науки та практики. - 2014. - № 1 (14). - С. 4-5.

5. Герасимов В. М. Амінокислотний склад ефіроолійних видів роду деревій флори України / В. М. Герасимов, О. В. Мазулін, О. М. Денисенко // Фармацевтичний журнал. - 2006. - № 3. - С. 90-92.

6. Гонський Я. І. Біохімія людини : підручник / Я. І. Гонський, Т. П. Максимчук. - Тернопіль : Укрмедкнига, 2001. - 736 с.

7. Малий В.В. Амінокислотний склад сировини поширених рослин роду Caprifoliaceae та Aceraceae // Фармацевтичний часопис. - 2010. - № 3. - С. 20-22.

ISSN 2312-0967. Pharmaceutical review. 2015. № 1 
8. Лукманова К. А. Аминокислотный и минеральный состав фитопрепарата люцерон / К. А. Лукманова, В. А. Рябчук, Н. Х. Салихова // Фармация. - 2000. № 2. - C. 25-27.

9. Марчишин С. М. Дослідження амінокислот трави розхідника звичайного (Glechoma hederacea L.) / С. М. Марчишин, М. С. Гарник // Український біофармацевтичний журнал. - 2013. - № 3(26). - С. 40-43. 10. Jambor A. Amino acids analysis by high-performance liquid chromatography after derivatization with 9fluorenylmethyloxycarbonyl chloride. Literature overview and further study / A. Jambor, I. Molnar-Perl // Journal of Chromatography A. - 2009. - № 1216. - P. 3064-3077. 11. John W. Henderson. Accurate, Sensitive, and Reproductible HPLC Analysis of Amino Acids. Amino Acids Analysis Using Zorbax Eclipse-AAA Columns and the Agilent 1100 HPLC / John W. Henderson, Robert D. Ricker, Brian A. Bidlingmeyer, Cliff Woodward Rapid // Agilent Technical Note. - 1999. - P. 5980-1193.
12. Jambor A. Quantitation of amino acids in plasma by high performance liquid chromatography: Simultaneous deproteinization and derivatization with 9?uorenylmethyloxycarbonyl chloride / A. Jambor, I. Molnar-Perl // Journal of Chromatography A. - 2009. № 1216. - P. 6218-6223.

13. Que F. In vitro and vivo antioxidant activities of daylily flowers and the involvement of phenolic compounds / F. Que, L. Mao, X. Zheng // Asia Pac J Clin Nutr. - 2007; Department of Food Science and Nutrition, College of Biosystem Engineering and Food Science, Zhejiang University, Hangzhou, China 310029. US National Library of Medicine. National Institutes of Health. Life Sci. - 2004. - June 25, № 75. - P. 753-763.

14. Shih-Hang Lin. The Antidepressant-like Effect of Ethanol Extract of Daylily Flowers in Rats / Shih-Hang Lin, Hui-Chi Chang, Pei-Ju Chen [et al.] // Journal of Traditional and Complementary Medicine - 2013. - Vol. 3, Issue 1. P. 53-61.

\title{
СОДЕРЖАНИЕ АМИНОКИСЛОТ В ПОДЗЕМНЫХ И НАДЗЕМНЫХ ОРГАНАХ ЛИЛЕЙНИКА БУРО- ЖЕЛТОГО (HЕMEROCALLIS FULVA L.) И ЛИЛЕЙНИКА ГИБРИДНОГО (HЕMEROCALLIS HYBRIDA VAR. "STELLA DE ORO»)
}

\author{
С. М. Марчишин ${ }^{1}$, Е. В. Заричанская² \\ ${ }^{1}$ Тернопольский государственный медицинский университет имени И. Я. Горбачевского \\ ${ }^{2}$ Винницкий национальный медицинский университет имени Н. И. Пирогова
}

\begin{abstract}
Резюме: проведено исследование аминокислотного состава корнеклубней, листьев и цветков лилейника бурожелтого (Hemerocallis fulva L.) и лилейника гибридного (Hemerocallis hybrida var. «Stella De Oro»). Методом високоэффективной жидкостной хроматографии на приборе Agilent 1100 (США) определено общее содержание аминокислот в сырье и содержание свободных аминокислот. Идентифицированы 17 аминокислот, 9 из которых являються незаменимыми. Установлено их количественное содержание.
\end{abstract}

Ключевые слова: аминокислоты, надземные и подземные органы, лилейник буро-желтый, лилейник гибридный, высокоэффективная жидкостная хроматография.

\section{CONTENT OF AMINO ACIDS IN UNDERGROUND AND AERIAL PARTS OF ORANGE DAYLILY (HEMEROCALLIS FULVA L.) AND HYBRID DAYLILY (HEMEROCALLIS HYBRIDA VAR. "STELLA DE ORO”)}

\section{S. M. Marchyshyn ${ }^{1}$, O. V. Zarichanska ${ }^{2}$ \\ ${ }^{1}$ Ternopil State Medical University by I. Ya. Horbachevsky \\ ${ }^{2}$ Vinnytsia National Medical University by M. I. Pyrohov}

Summary: amino acids composition of modified roots, leaves and flowers of orange daylily (Hemerocallis fulva L.) and hybrid daylily (Hemerocallis hybrida var. «Stella De Oro») was studied. Using apparatus Agilent 1100 (USA) total content of amino acids and content of free amino acids in plant raw material was investigated by the method of high performance liquid chromatography. 17 amino acids, including 9 essential ones, was revealed. Their quantitative content was determined.

Key words: amino acids, overground and underground organs, orange daylily, hybrid daylily, high-performance liquid chromatography. 